\title{
Enchondromas of Long Bones and Other Skeletal Lesions Found Incidentally Need Critical Evaluation, But Rarely Systematic Follow-Up
}

\author{
G. Ulrich Exner1 ${ }^{1}$, Pascal A. Schai², Nadja Mamisch-Saupe ${ }^{3}$, Michael 0. Kurrer ${ }^{4}$ \\ ${ }^{1}$ Orthopaedie Zentrum Zuerich, Zuerich, Switzerland \\ ${ }^{2}$ Luzerner Kantonsspital Wolhusen, Wolhusen, Switzerland \\ ${ }^{3}$ Radiologie Klinik Hirslanden, Klinik Hirslanden, Witellikerstr, Zuerich \\ ${ }^{4}$ Pathologikum, Gemeinschaftspraxis für Pathologie, Seefeldstr, Zuerich \\ Email: guexner@gmail.com, pascal.schai@luks.com, Nadja.mamisch@hirslanden.ch,pathologikum@hin.ch
}

How to cite this paper: Exner, G.U., Schai, P.A., Mamisch-Saupe, N. and Kurrer, M.O. (2022) Enchondromas of Long Bones and Other Skeletal Lesions Found Incidentally Need Critical Evaluation, But Rarely Systematic Follow-Up. Open Journal of Orthopedics, 12, 66-78.

https://doi.org/10.4236/ojo.2022.122008

Received: January 28, 2022

Accepted: February 25, 2022

Published: February 28, 2022

Copyright $\odot 2022$ by author(s) and Scientific Research Publishing Inc. This work is licensed under the Creative Commons Attribution International License (CC BY 4.0).

http://creativecommons.org/licenses/by/4.0/

(c) (i) Open Access

\begin{abstract}
Purpose: Incidental bone lesions are a challenge for the specialist, who has to give recommendations for further management. This review of our cases will assist in the decision whether the lesion can be "neglected", needs further active follow-up or direct initiation of treatment. Patients and Methods: 153 cases of incidental bone findings were presented to our musculoskeletal tumor service for evaluation from July 2008 through June 2021.73 of them were cartilaginous tumors and 63 of these were diagnosed as enchondroma of a long bone based on X-Ray and MRI. Results: Follow-up imaging of the enchondroma patients was available for 35 patients at 1 to 13 years (mean $4.3 \mathrm{y}$ ), with no change in size except for one femoral diaphyseal enchondroma with increasing diameter from age 18 to 20 years. 14 additional patients answered written contact stating that they remained asymptomatic at 2 to 12 years (mean $5.6 \mathrm{y}$ ). None of the patients has been reported to the Swiss Confoederation Cancer Registry to have developed malignancy. Among the 10 other cartilaginous tumors were one chondrosarcoma grade II exhibiting different imaging, 3 non-long-bone localizations (pelvis, scapula and rib), 2 Ollier-type enchondromas, and 2 osteochondromas. Incidental findings other than cartilaginous tumors were fibrous dysplasia $(n=31)$, nonossifying fibroma $(\mathrm{n}=31)$ and 18 other "sporadic" entities. Conclusions: Incidentally found enchondromas not exhibiting aggressive features need no systematic follow-up and patients can be "discharged" with the advice to present, if symptoms would develop. This also applies to fibrous dysplasia
\end{abstract}


and the other sporadic lesions. 6 cases with other diagnoses needed specific treatment.

\section{Keywords}

Incidental Bone Lesions, Enchondroma, Fibrous Dysplasia, Non-Ossifying Fibroma

\section{Introduction}

Each case presenting with an incidental finding in musculoskeletal imaging raises concern regarding diagnosis and further management.

Among the series of incidental bone findings referred to our tumor group for evaluation cartilaginous tumors were the most frequent, usually referred with the objective to "rule out sarcoma".

Several authors (Patel et al. [1], Davies et al. [2], and Ahmed et al. [3]) recently questioned, whether follow-up imaging is needed in incidentally found painless chondroid lesions in long bones without aggressive features in imaging.

Historically the risk of developing chondrosarcoma ex enchondroma has been overestimated, as enchondromas were detected in standard radiographs only in the presence of distinct calcifications. In the era of MRI, enchondromas are found more frequently, and with a prevalence of $2.8 \%$ in knee MRI according to Stomp et al. [4] may be regarded as a "normal concurrent finding".

With our data, we wish to contribute to the discussion of how to proceed with enchondromas found incidentally regarding follow-up. We also include the other incidental bone lesions to expand on differential diagnostic aspects.

\section{Materials and Methods}

\section{Patients}

153 cases have been referred by orthopaedic surgeons to our dedicated musculoskeletal tumor group for the evaluation of incidental bone findings from July 2008 through June 2021. Imaging was performed in most patients because of shoulder or knee problems. All patients had standard X-Ray and MRI documentation. The diagnoses as an incidental finding were based upon the patients' history and physical examination and are summarized in Table 1.

Based on X-Ray and MRI 73 of the patients had cartilaginous tumors and 63 of these were diagnosed as enchondroma of a long bone. One of the 63 had bilateral enchondromas in the distal femur. Histologic examinations were performed on 5 of the 63 enchondroma cases. One humeral lesion was curetted elsewhere for suspected chondrosarcoma and eventually diagnosed as enchondroma without atypia; one patient with a distal tibia enchondroma had a biopsy as an external radiology expert felt another entity needed to be ruled out. 
Table 1. List of incidentally found bone lesions regarding diagnosis, size of the enchondromas, management and follow-up data.

\begin{tabular}{|c|c|c|c|c|c|c|}
\hline \multicolumn{7}{|c|}{ Incidental Bone Lesions } \\
\hline Localization & $\mathrm{n}$ & $\begin{array}{l}\text { Age } \\
\text { Range } \\
\text { (Mean) }\end{array}$ & $\begin{array}{l}\text { Maximum } \\
\text { diameter } \\
\text { Range } \\
\text { (Mean) }\end{array}$ & $\begin{array}{l}\text { Cortical contact } \\
\text { (n) } \\
\text { Scalloping }\end{array}$ & Management & $\begin{array}{l}\text { Follow-up } \\
\text { Range } \\
\text { (Mean) }\end{array}$ \\
\hline \multicolumn{7}{|c|}{ Enchondroma long bones $\mathrm{n}=63$, for illustration see Figures $1-3$} \\
\hline $\begin{array}{l}\text { Humerus } \\
\text { proximal }\end{array}$ & 18 & $\begin{array}{l}38-77 y \\
(53 y)\end{array}$ & $\begin{array}{l}1.0-8.0 \mathrm{~cm} \\
(4.5 \mathrm{~cm})\end{array}$ & $\begin{array}{l}\text { Scalloping }<1 / 3 \\
\text { in } 2,>2 / 3 \text { in } 2 \\
\text { no change } \\
\text { during } 3 \mathrm{y} f / \mathrm{u} \\
\text { Other patients } \\
\text { no scalloping }\end{array}$ & $\begin{array}{l}1 \text { biopsied at } \\
\text { arthroscopy } \\
1 \text { curetted to exclude } \\
\text { sarcoma; } \\
\text { Histology on both } \\
\text { "enchondroma" }\end{array}$ & $\begin{array}{l}\text { Imaging for } 12 \text { patients } \\
\text { available at } \\
1-7 \mathrm{y}(3.69 \mathrm{y}) \text { no } \\
\text { change } \\
\text { Clinically asymptomatic } \\
4 \text { additional patients at } \\
4,9,10,12 \mathrm{y}\end{array}$ \\
\hline $\begin{array}{l}\text { Humerus } \\
\text { diaphysis }\end{array}$ & 2 & $42-53 y$ & $1.5 / 9.0 \mathrm{~cm}$ & No scalloping & & $\begin{array}{l}1 \text { patient asymptomatic } \\
\text { at } 12 \mathrm{y}\end{array}$ \\
\hline $\begin{array}{l}\text { Femur } \\
\text { distal }\end{array}$ & 27 & $\begin{array}{l}34-72 y \\
(50.8 y)\end{array}$ & $\begin{array}{l}0.8-11.0 \mathrm{~cm} \\
(3.5 \mathrm{~cm})\end{array}$ & $\begin{array}{l}\text { Only the patient } \\
\text { with the } 11 \mathrm{~cm} \\
\text { long } \\
\text { enchondroma } \\
\text { had minimal } \\
\text { scalloping } \\
\text { remaining } \\
\text { unchanged at } 7 \mathrm{y} \\
\mathrm{f} / \mathrm{u}\end{array}$ & $\begin{array}{l}2 \text { cases curetted and } \\
\text { filled with graft to } \\
\text { prepare for cruciate } \\
\text { ligament } \\
\text { reconstruction/knee } \\
\text { replacement } \\
\text { Histology: } \\
\text { enchondroma }\end{array}$ & $\begin{array}{l}\text { Imaging for } 9 \text { patients } \\
\text { available at } \\
1-7 \mathrm{y}(3.4 \mathrm{y}) \\
\text { no change } \\
8 \text { additional patients } \\
\text { asymptomatic at } \\
2-10 \mathrm{y}(5.6 \mathrm{y})\end{array}$ \\
\hline $\begin{array}{l}\text { Femur } \\
\text { mid-diaphysis }\end{array}$ & 4 & $\begin{array}{l}18-34 y \\
(26.5 y)\end{array}$ & $\begin{array}{l}2.7-4.6 \mathrm{~cm} \\
(3.3 \mathrm{~cm})\end{array}$ & No scalloping & & $\begin{array}{l}1 \text { patient followed from } \\
\text { age } 18 \text { y to age } 20 \mathrm{y} \\
\text { showed increase } \\
\text { in diameter } \\
\text { from } 3.2 \text { to } 4.6 \mathrm{~cm} \\
\text { without scalloping-to } \\
\text { be followed }\end{array}$ \\
\hline Femur proximal & 2 & $62 / 51$ y & $7.0 / 2.3 \mathrm{~cm}$ & $\begin{array}{l}\text { No cortical } \\
\text { contact }\end{array}$ & & $\begin{array}{l}\text { Imaging for } 1 \text { patient at } \\
2 y-\text { no change }\end{array}$ \\
\hline $\begin{array}{l}\text { Tibia } \\
\text { proximal }\end{array}$ & 4 & $\begin{array}{l}22-55 y \\
(45 y)\end{array}$ & $\begin{array}{l}2.1-6.8 \mathrm{~cm} \\
(4.0 \mathrm{~cm})\end{array}$ & $\begin{array}{l}1 \text { mild } \\
\text { scalloping } \\
\text { eccentric lesion } \\
\text { unchanged over } \\
4 \mathrm{y} \mathrm{f/u}\end{array}$ & & $\begin{array}{l}\text { Imaging available for } 3 \\
\text { patients at } \\
3,4,8 \mathrm{y}-\text { No change }\end{array}$ \\
\hline $\begin{array}{l}\text { Tibia } \\
\text { distal }\end{array}$ & 1 & $53 \mathrm{y}$ & $3.0 \mathrm{~cm}$ & $\begin{array}{l}\text { Eccentric with } \\
\text { extracortical } \\
\text { extrusion }\end{array}$ & $\begin{array}{l}\text { Biopsy: benign } \\
\text { enchondroma }\end{array}$ & No f/u \\
\hline
\end{tabular}




\section{Continued}

\begin{tabular}{|c|c|c|c|c|c|c|}
\hline $\begin{array}{l}\text { Fibula } \\
\text { proximal }\end{array}$ & 5 & $\begin{array}{l}43-59 y \\
(52 y)\end{array}$ & $\begin{array}{l}1.0-4.5 \mathrm{~cm} \\
(2.9 \mathrm{~cm})\end{array}$ & $\begin{array}{l}\text { All patients } \\
\text { showed some } \\
\text { scalloping in the } \\
\text { fibular head }\end{array}$ & $\begin{array}{l}1 \text { curetted, bone } \\
\text { plasty } \\
\text { enchondroma }\end{array}$ & $\begin{array}{l}\text { Imaging available for } 6 \\
\text { patients at } \\
3-13 \mathrm{y}(7.4 \mathrm{y}) \\
\text { no change; } \\
2 \text { additional patient } \\
\text { asymptomatic at } \\
3,12 \mathrm{y}\end{array}$ \\
\hline
\end{tabular}

Other cartilaginous lesions $\mathrm{n}=10$

\begin{tabular}{|c|c|c|c|c|c|}
\hline $\begin{array}{l}\text { Diagnosis/ } \\
\text { Localization }\end{array}$ & $\mathrm{n}$ & Age & Remarks & Treatment & \\
\hline $\begin{array}{l}\text { Chondrosarcoma } \\
\text { grade II } \\
\text { proximal Tibia }\end{array}$ & 1 & $30 y$ & Figure 4 & $\begin{array}{l}\text { Wide resection, } \\
\text { endoprosthesis }\end{array}$ & \\
\hline $\begin{array}{l}\text { Enchondroma } \\
\text { type Ollier } \\
\text { Femur distal }\end{array}$ & 1 & $53 \mathrm{y}$ & & Observation & \\
\hline $\begin{array}{l}\text { Enchondroma } \\
\text { type Ollier } \\
\text { Tibia distal }\end{array}$ & 1 & $34 \mathrm{y}$ & & Observation & \\
\hline $\begin{array}{l}\text { Osteochondroma } \\
\text { Fibula }\end{array}$ & 3 & $\begin{array}{l}21-56 y \\
(42 y)\end{array}$ & & Resection & \\
\hline $\begin{array}{l}\text { Periosteal } \\
\text { chondroma } \\
\text { Femur distal }\end{array}$ & 1 & $34 \mathrm{y}$ & & Wide resection & \\
\hline $\begin{array}{l}\text { Chondrosarcoma } \\
\text { exostotic grade I } \\
\text { Scapula }\end{array}$ & 1 & $19 y$ & & Wide resection & At $\mathrm{f} / \mathrm{u} 4$ y no recurrence \\
\hline $\begin{array}{l}\text { Myxoid } \\
\text { chondrosarcoma } \\
\text { Pelvis }\end{array}$ & 1 & $31 \mathrm{y}$ & & Wide resection & \\
\hline $\begin{array}{l}\text { Enchondroma } \\
\text { Rib }\end{array}$ & 1 & $35 \mathrm{y}$ & & Observation & At $2 \mathrm{y} f / u$ unchanged \\
\hline
\end{tabular}

Fibrous dysplasia including LSMFT, for illustration see Figure 5

Femur 13, Pelvis

7, Rib 1, Ulna 1, $31 \quad 11-72 \mathrm{y}$

Fibula 2, Tibia $7 \quad(43 \mathrm{y})$

4 cases biopsy proven

Non-ossifying fibromal fibrous cortical defect, for illustration see Figure 6

\begin{tabular}{lll}
\hline & Non-ossifying fibromal fibrous cortical defect, for & illustration see Figure 6 \\
\hline $\begin{array}{l}\text { NOF/Fibrous } \\
\text { histiocytoma }\end{array}$ & 31 & $\begin{array}{l}3-52 \mathrm{y} \\
(22 \mathrm{y})\end{array}$
\end{tabular}




\section{Continued}

\section{Other incidental findings $\mathrm{n}=18$}

\section{Cortical}

desmoid Femur

kondyle

$10-24$ y Reference

(16.8 y) [26]

Reference

Exner [29]

\section{bone cyst}

1

$4 \mathrm{y}$

Humerus

Simple juvenile bone cyst distal

Fibula

Periosteal

vascular

malformation

distal Femur

\begin{tabular}{|c|c|c|c|}
\hline $\begin{array}{l}\text { Calcaneus } \\
\text { Cysts/Lipomas }\end{array}$ & 7 & $\begin{array}{l}12-71 y \\
(35 y)\end{array}$ & $\begin{array}{l}\text { Reference } \\
\text { Malghem } \\
{[28]}\end{array}$ \\
\hline
\end{tabular}

Osteopoikily

No long

bones
Spontaneous

regression

Observation

Observation

Observation

Biopsy/observation

1 filled with DBF at

same time as

resection of fibula

osteochondroma;

2 "prophylactically" filled with DBF

affected

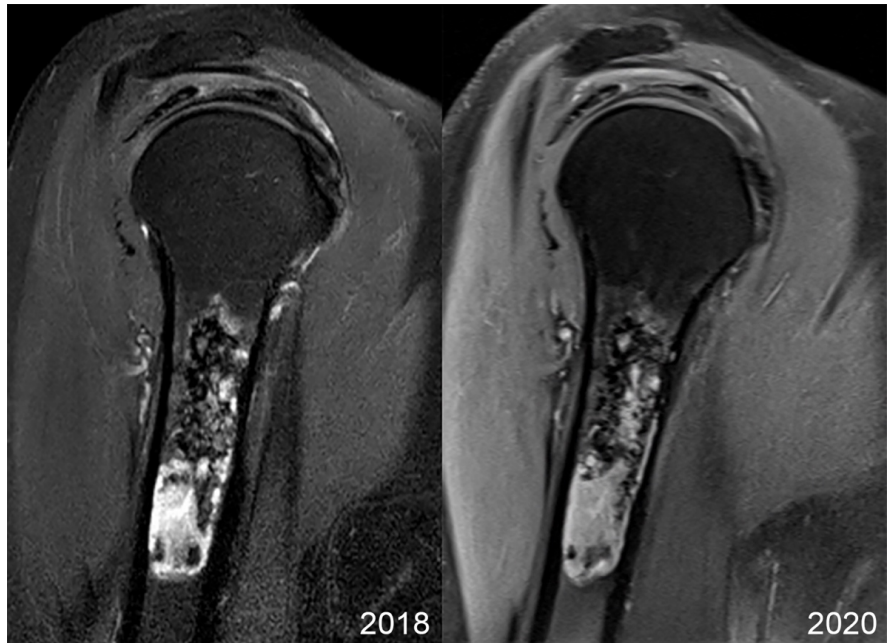

Figure 1. Female, 60 years: Enchondroma. MRI for rotator cuff evaluation. Proton-density-fat-saturated images show the enchondroma with a length of $63 \mathrm{~mm}$ unchanged over 2.8 years. 


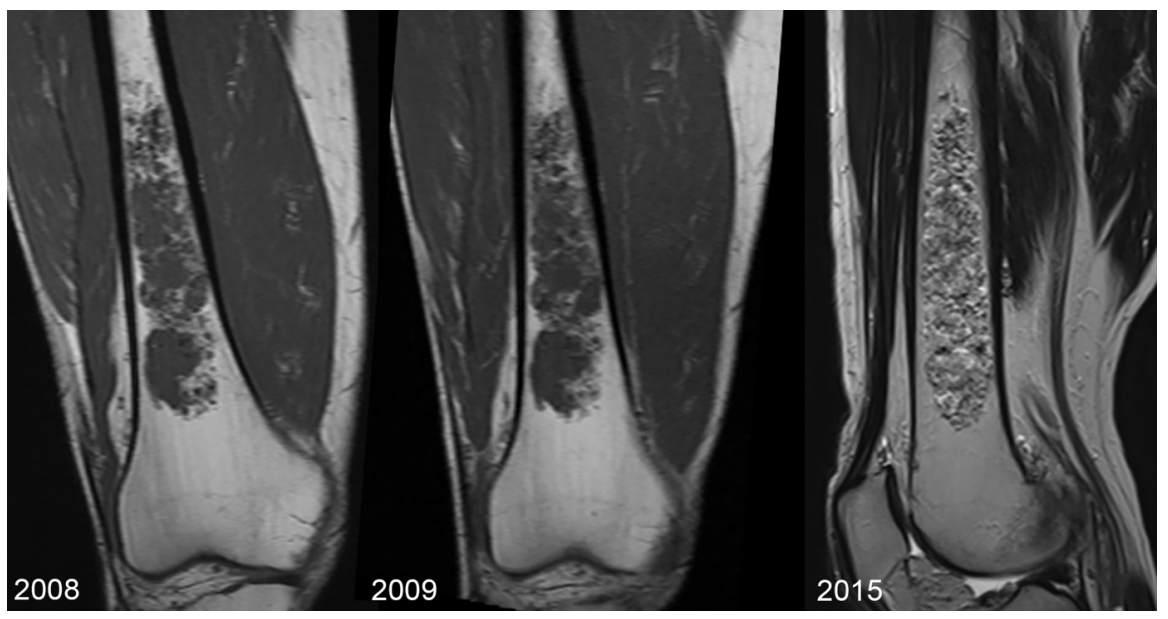

Figure 2. Male, 63 years: Enchondroma. MRI for evaluation of meniscal problems. The length $(126 \mathrm{~mm})$ and structural characteristics of "rings and arcs" remained unchanged over 7 years. In 2015 only sagittal images were provided. Clinically the patient is asymptomatic in 2021 .

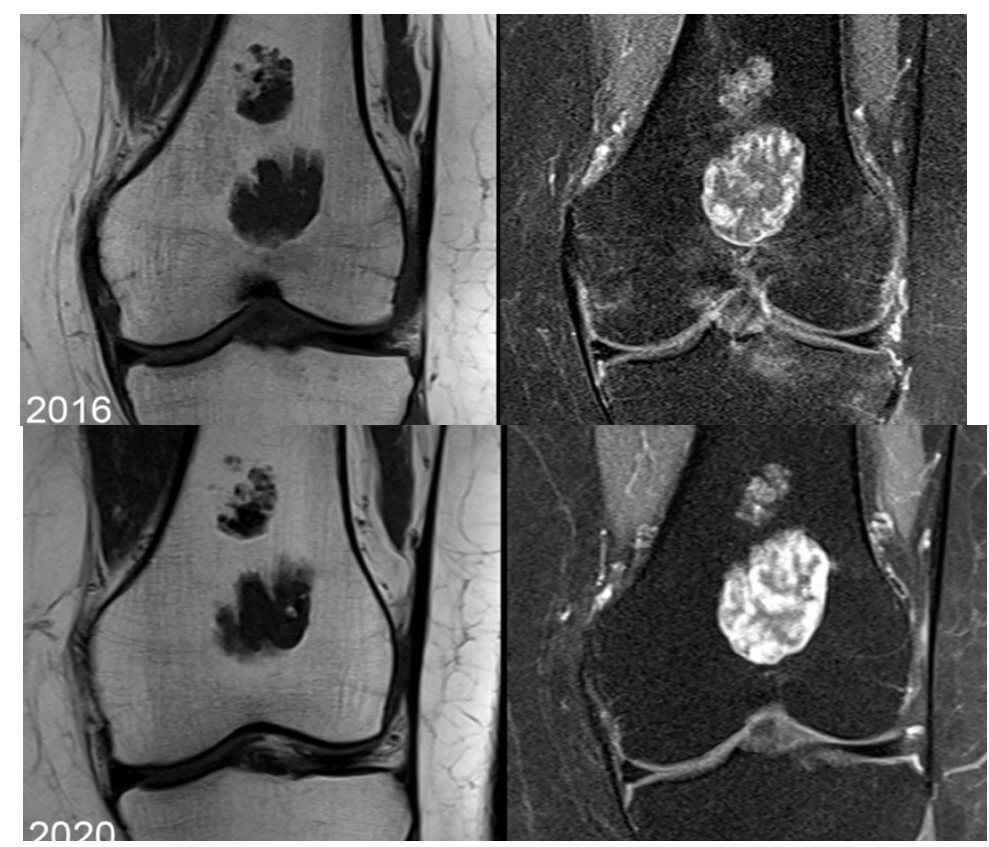

Figure 3. Female, 50 years: Enchondroma. Knee MRI for evaluation after contusion of the knee joint. The presentation of two separate lesions is unusual, but the images are typical for a chondroid matrix with inhomogenous contrast enhancement in the $\mathrm{T} 1$ weighted fat saturated images. No increase in size over the 4.5 years follow-up (top 2016, bottom 2020).

Two enchondroma cases of the femur found incidentally were curetted and filled with bone to prepare for later knee replacement or cruciate ligament reconstruction respectively; one proximal fibula enchondroma was curetted elsewhere.

One 30-year-old patient with an atypical radiological finding in the MRI performed for suspected ligament injury from distorsion of the knee joint (Figure 4) was eventually diagnosed as chondrosarcoma grade II of the medial tibial pla- 
teau and treated by wide resection and endoprosthetic reconstruction.

It is mandatory to report any malignant tumor including atypical chondromatous lesions to the Swiss Confoederation Cancer Registry. None of the patients of this study has been recorded up to January 2022, thus further documenting uneventful development.

Other cartilaginous lesions considered to be enchondromas type Ollier ( $\mathrm{n}=$ 3 ), and osteochondromatous lesions are listed for completeness.

Follow-up with imaging had been recommended to the referring colleagues at first presentation. Request for follow-up information was written at the time of this study. Patients were also asked for information about their present health.

\section{Results}

Follow-up imaging is available for 35 of the 63 enchondroma patients at 1 to 13 years (mean 4.3 years) with no change in size, except for one femoral diaphyseal enchondroma with increasing diameter from $3.4 \mathrm{~mm}$ at age 18 years to $4.2 \mathrm{~mm}$ at age 20 years. 14 patients answering to personal contact by phone or letter responded to have remained asymptomatic at follow-up over 2 to 12 years (mean 5.6 years). 14 patients could not be contacted because of having moved to an unknown address.

The data of the enchondroma and non-enchondroma lesions are summarized in Table 1. MRIs of representative cases of enchondroma, chondrosarcoma, fibrous dysplasia and non-ossifying fibromas are presented in Figures 1-6.

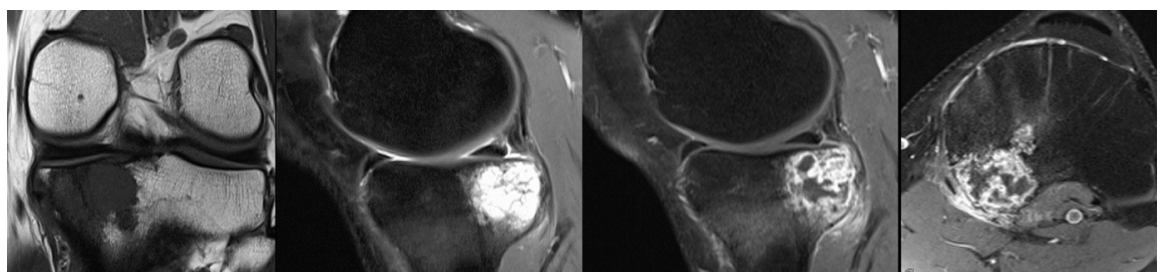

Figure 4. Male, 31 years: Chondrosarcoma grade II. MRI performed for suspected meniscal lesion after distorsion of the knee joint. The pattern is consistent with a ring-and-arc chondroid matrix. However, it exhibits aggressive features such as endosteal scalloping and soft tissue extension. Furthermore, the intraepiphyseal location must raise suspicion for an atypical process.

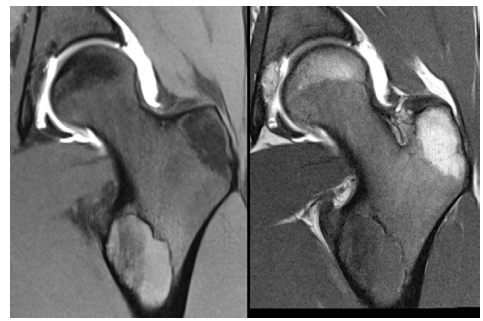

Figure 5. Female, 23 years: Fibrous dysplasia. Arthro-MRI was performed for suspected labral lesion. Localized defect in osteoblastic differentiation and maturation with replacement of normal bone by large fibrous stroma. Coronal proton density weighted image with fat saturation (left) showing higher signal compared to the T1 weighted image (right). Physiologic signal in the femoral head and greater trochanter. 


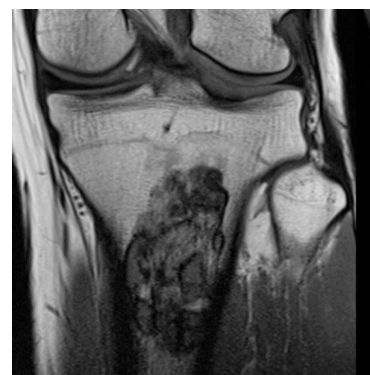

(a)

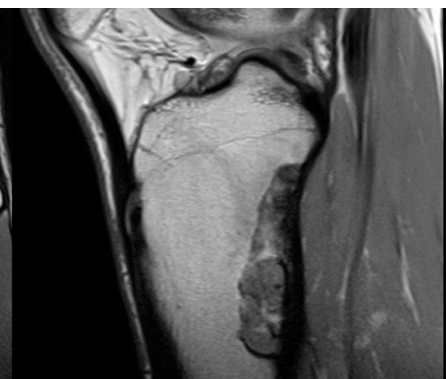

(b)

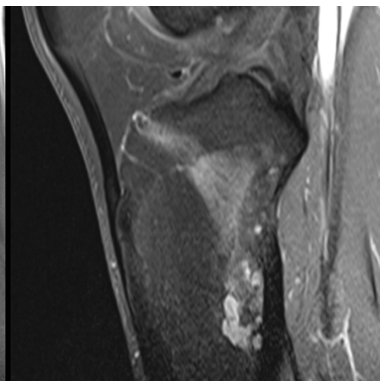

(c)

Figure 6. Male, 19 years: Large non-ossifying fibroma/fibrous cortical defect. This lesion already "matured" with ossification and consequently low signal on all sequences; T1 (a); proton density weighted (b); T1 fat-saturated and contrast enhancement (c).

\section{Discussion}

The purpose of this study is to assist in the decision making when faced with an incidental long bone finding presented to a musculoskeletal specialist.

Extensive literature upon the question of how to manage incidental orthopaedic findings exists; we, therefore, cite only a few selected references (Kim et al. [5], Velasco et al. [6], Nguyen et al., [7], Hiremath et al. [8], du Preez et al. [9]). Vanel et al. [10], Notrott et al. [11]).

Until recently follow-up imaging of incidentally found enchondromas has been generally considered mandatory. Since this strategy has been challenged by Ahmed et al. [3], we wish to contribute to this question with our data. In addition, we want to shed some light on other incidental bone findings.

Diagnoses encountered in our cases have been as follows.

\subsection{Enchondroma}

Tumors producing a chondroid matrix are histologically classified as cartilaginous neoplasms (Fletcher et al. [12]) and comprise a spectrum ranging from resting lesions to highly aggressive malignant neoplasms. Enchondroma, periosteal chondroma, enchondromatosis (Ollier and Maffucci Syndrome) and osteochondroma ("exostosis") are benign tumors grouped together as chondromas, pathologically sharing hyaline cartilage. Chondroblastoma, chondromyxoid fibroma and synovial chondromatosis also exhibit cartilaginous differentiation.

Chondrosarcomas are malignant cartilage-differentiating tumors graded usually II or III.

Enchondromas are benign cartilaginous neoplasms that develop within the medullary space of bone and are derived from growth plate chondrocytes in bone (Milgram et al. [13], Zhang et al. [14]). Enchondromatous lesions continuing to grow and exhibiting destructive features have historically been reported as lowgrade chondrosarcoma, grade 1 . However, as they do not metastasize and therefore don't fulfill criteria for malignancy, recently they are reported as central atypical cartilaginous tumor and should no longer bear the label "sarcoma" (WHO Classification of Tumours [12]. 
The differentiation between enchondroma and central atypical cartilaginous tumor hinges on imaging features as the histology may be identical (Nguyen et al. [7]). Aggressive features suggesting chondrosarcoma include endosteal scalloping more than two third of length of the lesion, large non-calcified component, and larger lesions (Murphey et al. [15], Choi et al. [16]). Choi et al. [16] in their study of 18 patients with low-grade chondrosarcoma and 16 patients with enchondroma, both groups with histo-pathological examinations, found higher incidence of predominantly intermediate signal in T1-weighted images, multilocular appearance on contrast-enhanced T1-weighted images, cortical destruction, soft tissue mass and adjacent abnormal bone marrow and soft tissue signal among the low-grade chondrosarcoma cases.

Scalloping is seen in most cases of proximal fibula and humeral head enchondromas, which may be explained by the thin cortex, and in these locations not necessarily indicate aggressiveness.

However, there are no clear-cut imaging criteria to separate enchondroma from low-grade chondrosarcoma with a high interobserver inconsistency regarding diagnosis and grading (Geirnaerdt et al. [17]), Jones et al. [18], Gelderblom et al. [19], Deckers et al. [20], Eefting et al. [21]).

Endosteal scalloping was found to allow differentiation between enchondroma and chondrosarcoma when involving more than one-third of the lesion (Murphey et al. [15]). Longitudinal tumor extent more than $5 \mathrm{~cm}$ was found to be a predictable indicator of malignancy (Geirnaerdt et al. [17]).

However, the data indicate a low risk for the evolution from quiescent enchondroma to a more active atypical chondromatous lesion (a nomenclature now replacing the description as low grade (I) chondrosarcoma). They are therefore actually considered as "leave alone lesions"; patients should be informed about the benign nature and to watch development and present again, when the incidental lesion becomes symptomatic.

The data furthermore do not support the recommendation of curettage of enchondromas and atypical chondromatous tumors still frequently advocated (e.g. Deckers et al. [22]) which is associated naturally with a certain rate of complications.

If control of the incidental lesion by repeat imaging is recommended this should be at long intervals, e.g. 3 to 5 years. First, this would save expenses and secondly this warrants that the patient does not get "tired" from follow-up before changes can be expected.

The few lesions found larger than $5 \mathrm{~cm}$ longitudinal extent in our patients even in the presence of scalloping showed no progression within the time frame of observation (Figures 1-3).

\subsection{Other Incidentally Found Lesions}

Osteochondromas are readily diagnosed and except for cases with a large cartilaginous cap can be resected without further preoperative investigations (WHO 
classification of Tumours [12]). The terminology “(osteo-)cartilaginous exostoses" is not any longer recommended (WHO classification of Tumours [12]).

Fibrous dysplasia typically presents an incidental finding in its monostotic form. Follow-up consultation is needed only when symptoms develop (DiCaprio et al. [23]).

The liposclerosing myxofibrous tumor (LSMFT) is a benign fibro-osseous lesion, has distinct radiographic features and is generally diagnosed incidentally (Deel et al. [24]). Heim et al. [25] proposed that LSMFT probably represents a traumatized variant of fibrous dysplasia and involutional/ischemic changes can be so extensive that residual fibrous dysplasia areas are completely absent.

Non-ossifying fibromas are easily diagnosed and rarely need intervention, but apparently, even orthopaedic surgeons may have difficulties to make the diagnosis especially in larger lesions (Herget et al. [26]).

The so-called periosteal desmoids are mentioned as we consider them normal variants of no relevance except for ruling out neoplasms mimicking these minor abnormalities (Tscholl et al. [27]).

Clinical relevance of calcaneal cysts depends upon size (Pogoda et al. [28]). It is of interest that calcaneal cysts and calcaneal lipomas may be a single entity and a pathogeneic continuity may exist (Malghem et al. [29]).

The incidentally found case of the osteofibrous dysplasia with rhabdoid elements and spontaneous resolution has been published recently (Exner et al. [30]).

\section{Drawbacks and Limitations of This Study}

Follow-up of the patients in our observational group is incomplete and with an average of 4.1 years short for lesions, which only at very long term, probably decades, may change their activity.

Patients not followed by the authors usually stay in the initial medical setting; therefore they most likely would have presented to the referring orthopaedist or to our group in case of symptoms or imaging changes of their bone lesion.

Furthermore, the diagnoses were almost exclusively based on imaging findings alone.

Other lesions that typically present incidentally as e.g. intraosseous hemangioma were not encountered in this series but need to be recognized.

\section{Summary and Conclusions}

Our findings agree with those of Ahmed et al. [3], Patel et al. [1], and Davies et al. [29] that asymptomatic patients with long bone enchondromas less than $5 \mathrm{~cm}$ longitudinal extension with no endosteal scalloping do not need systematic imaging follow-up and can be discharged after explanation of the diagnosis and instruction to seek medical attention in case of any change, development of discomfort or increasing pain.

The lesions larger than $5 \mathrm{~cm}$ have remained stable in our patients; however, 
follow-up is too short to exclude progression into chondrosarcoma grade II or even grade III at longer intervals. Therefore we cannot provide data on the time interval needed to develop dedifferentiation. Until more data are available it may therefore be cautious to repeat imaging. This, however, should be done at rather longer time intervals; 5-year intervals may be reasonable as with shorter intervals patients not seeing definitive progression would become reluctant to submit to further examinations creating unnecessary concerns and last but not least costs. We hope that systematic follow-up data will add to the scientifically based care of patients with incidentally found enchondromas.

\section{Ethical Approval}

The study was approved by the institutional review boards.

\section{Informed Consent}

Informed consent was obtained from all patients.

\section{Authors' Contribution}

The first author collected the data, all authors contributed equally to the evaluation and interpretation of images, and finalizing the manuscript.

\section{Conflicts of Interest}

There are no conflicts of interest.

\section{References}

[1] Patel, A., Davies, A., Botchu, R. and James, S. (2019) A Pragmatic Approach to the Imaging and Follow-Up of Solitary Cartilage Tumours of the Proximal Humerus and Knee. Clinical Radiology, 74, 517-526. https://doi.org/10.1016/j.crad.2019.01.025

[2] Davies, A., Patel, A., James, S. and Botchu, R. (2019) A Retrospective Validation of an Imaging Protocol for the Management of Solitary Central Cartilage Tumours of the Proximal Humerus and around the Knee. Clinical Radiology, 74, 962-971. https://doi.org/10.1016/j.crad.2019.08.017

[3] Ahmed, S., Jubouri, S. and Mulligan, M. (2021) Incidental Long Bone Cartilage Lesions: Is Any Further Imaging Workup Needed? Skeletal Radiology, 50, 1189-1196. https://doi.org/10.1007/s00256-020-03664-w

[4] Stomp, W., Reijnierse, M., Kloppenburg, M., de Mutsert, R., Bovée, J.V.M.G., de heijer, M. and Bloem, J.L. (2015) Prevalence of Cartilaginous Tumours as an Incidental Finding on MRI of the Knee. European Radiology, 25, 3480-3487. https://doi.org/10.1007/s00330-015-3764-6

[5] Kim, L.T.S., Laible, C.N., Rybak, L.D. and Rapp, T.B. (2012) "Incidental” Bone Lesions. When to Refer to the Tumor Specialist. Bulletin of the NYU Hospital for Joint Diseases, 70, 215-240.

[6] Velasco, B.T., Ye, M.Y., Chien, B., Kwon, J.Y. and Miller, C.P. (2020) Prevalence of Incidental Benign Lesions on Radiographs Ordered by Orthopaedics Surgeons. Journal of the American Academy of Orthopaedic Surgeons, 28, e356-e362. 
https://doi.org/10.5435/JAAOS-D-19-00236

[7] Nguyen, M., Beaulieu, C., Weinstein, S. and Shin, L.K. (2017) The Incidental Bone Lesion on Computed Tomography: Management Tips for Abdominal Radiologists. Abdominal Radiology, 4, 1586-1605. https://doi.org/10.1007/s00261-016-1040-0

[8] Hiremath, S.B., Boto, J., Regnaud, A., Etienne, L., Fitsiori, A. and Vargas, M.I. (2019) Incidentalomas in Spine and Spinal Cord Imaging. Clinical Neuroradiology, 29, 191-213. https://doi.org/10.1007/s00062-019-00773-5

[9] du Preez, H., Lasker, I., Rajakulasingam, R. and Saifuddin, A. (2020) Whole-Body Magnetic Resonance Imaging: Incidental Findings in Paediatric and Adult Populations. European Journal of Radiology, 130, Article ID: 109156.

https://doi.org/10.1016/j.ejrad.2020.109156

[10] Vanel, D., Ruggieri, P., Ferrari, S., Picci, P., Gambarotti, M., Staals, E. and Alberghini, M. (2009) The Incidental Skeletal Lesion: Ignore or Explore. Cancer Imaging, 9, 38-43. https://doi.org/10.1102/1470-7330.2009.9009

[11] Notrott, M., Hardes, J., Gosheger, G. andreou, D., Henrichs, M. and Streitburger, A. (2014) Benigne Knorpeltumoren. Was mache ich mit dem Zufallsbefund. Unfallchirurg, 117, 905-914. https://doi.org/10.1007/s00113-014-2578-3

[12] WHO (2020) Classification of Tumours Editorial Board. Soft Tissue and Bone Tumours. 5th Edition, Vol. 3, WHO Classification of Tumours Series, International Agency for Research on Cancer, Lyon. https://publications.iarc.fr/588

[13] Milgram, J.W. (1983) The Origins of Oyteochondromas and Enchondromas. A Histopathologic Study. Clinical Orthopaedics and Related Research, 174, 264-284. https://doi.org/10.1097/00003086-198304000-00037

[14] Zhang, H. and Alman, B.A. (2021) Enchondromatosis and Growth Plate Development. Current Osteoporosis Reports, 19, 40-49.

https://doi.org/10.1007/s11914-020-00639-7

[15] Murphey, M.D., Flemming, D.J., Boyea, S.R., Bojescul, J.A., Sweet, D.E. and Temple, H.T. (1998) Enchondroma versus Chondrosarcoma in the Appendicular Skeleton: Differentiating Features. Radiographics, 18, 1213-1237.

https://doi.org/10.1148/radiographics.18.5.9747616

[16] Choi, B.B., Jee, W.-H., Sunwoo, H.-J., Cho, J.-H., Kim, J.Y., Chun, K.-A., Hong, S.-J., Chung, H. W., Sung, M.-S., Lee, Y.-S. and Chung, Y.-G. (2013) MR Differentiation of Low-Grade Chondrosarcoma from Enchondroma. Clinical Imaging, 37, 542-547. https://doi.org/10.1016/j.clinimag.2012.08.006

[17] Geirnaerdt, M.J., Hermans, J., Bloem, J.L., Kroon, H.M., Pope, T.L., Taminiau, A.H. and Hogendoorn, P.C. (1997) Usefulness of Radiography in Differentiating Enchondroma from Central Grade 1 Chondrosarcoma. AJR. American Journal of Roentgenology, 169, 1097-1104. https://doi.org/10.2214/ajr.169.4.9308471

[18] Jones, K., et al. (2007) Skeletal Lesions Interobserver Correlation among Expert Diagnosticians (SLICED) Study Group Reliability of Histopathologic and Radiologic Grading of Cartilaginous Neoplasms in Long Bones. The Journal of Bone and Joint Surgery, 89, 2113-2123. https://doi.org/10.2106/00004623-200710000-00003

[19] Gelderblom, H., Hogendoorn, P.C.W., Dijkstra, S.D., van Rijswijk, C.S., Krol, A.D., Taminiau, A.H.M. and Bovée, J.M.G. (2008) The Clinical Approach towards Chondrosarcoma. The Oncologist, 13, 320-329. https://doi.org/10.1634/theoncologist.2007-0237

[20] Deckers, C., Steyvers, M.J., Hannink, G., Schreuder, H.W.B., De Rody, J.W.J. and van der Geest, I.C.M. (2020) Can MRI Differentiate between Atypical Cartilaginous Tumors and High-Grade Chondrosarcoma? A Systematic Review. Acta Orthopae- 
dica, 91, 471-478. https://doi.org/10.1080/17453674.2020.1763717

[21] Eefting, D., Schrage, Y.M., Geirnaerdt, M.J.A., Le Cessie, S., Taminiau, A.H.M., Bovée, J.V.M.G. and Hogendorn, P.C.W. (2009) Assessment of Interobserver Variability and Histologic Paramters to Improve Reliability in Classification and Grading of Central Cartilaginous Tumors. The American Journal of Surgical Pathology, 33, 50-57. https://doi.org/10.1097/PAS.0b013e31817eec2b

[22] Deckers, C., de Leijer, E.M., Flucke, U., de Rooy, J.W.J., Schreuder, H.W.B., Dierselhus, E.F. and van der Geest (2021) Curettage and Cryosurgery for Enchondroma and Atypical Cartilaginous Tumors of the Long Bones: Oncological Results of a Large Series. Journal of Surgical Oncology, 123, 1821-1827. https://doi.org/10.1002/jso.26457

[23] DiCaprio, M.R. and Enneking, W.F. (2005) Current Concepts Review Fibrous Dysplasia Pathophysiology, Evaluation, and Treatment. The Journal of Bone and Joint Surgery, 87-A, 1848-1864. https://doi.org/10.2106/00004623-200508000-00028

[24] Deel, C. and Hassell, L. (2016) Liposclerosing Myxofibrous Tumor. A Review. Archives of Pathology \& Laboratory Medicine, 140, 473-476.

https://doi.org/10.5858/2014-0503-RS

[25] Heim-Hall, J.M. and Williams, R.P. (2004) Liposclerosing Myxofibrous Tumour: A Traumatized Variant of Fibrous Dysplasia? Report of Four Cases and Review of Literature. Histopathology, 45, 369-376. https://doi.org/10.1111/j.1365-2559.2004.01951.x

[26] Herget, G.W., Mauer, D., Krauss, T., El Tayeh, A., Suedkamp, N.P. and Hauschild, O. (2016) Non-Ossifying Fibroma: Natural History with an Emphasis on a Stage-Related Growth, Fracture Risk and the Need for Follow-Up. BMC Musculoskeletal Disorders, 17, 147-154. https://doi.org/10.1186/s12891-016-1004-0

[27] Tscholl, P.M., Biedert, R.M. and Gal, I. (2015) Cortical Desmoids in Adolescent Top-Level Athletes. Acta Radiologica Open, 4, 1-5. https://doi.org/10.1177/2058460115580878

[28] Pogoda, P., Priemel, M., Linhart, W., Stork, A., Adam, G., Windolf, J., Rueger, J. and Amling, M. (2004) Clinical Relevance of Calcaneal Bone Cysts. A Study of 50 Cysts in 47 Patients. Clinical Orthopaedics and Related Research, 424, 202-210. https://doi.org/10.1097/01.blo.0000128297.66784.12

[29] Malghem, J., Lecouvet, F. and Vande Berg, B. (2017) Calcaneal Cysts and Lipomas: A Common Pathogenesis? Skeletal Radiology, 46, 1635-1642. https://doi.org/10.1007/s00256-017-2688-4v

[30] Exner, G.U., von Hochstetter, A.R. and Pfirrmann, C.W.A. (2018) Osteofibrous Dysplasia with Rhabdoid Elements in a 38-Year-Old Man with Spontaneous Regression over 5 Years. JBJS Case Connector, 8, e51.

https://doi.org/10.2106/JBJS.CC.17.00294 